\title{
Internationalization in Engineering Education in English in Slovakia
}

\author{
BALÁŽOVÁ PAVLA \\ Faculty of Civil Engineering and Faculty of Arts \\ Slovak University of Technology in Bratislava and Comenius University in Bratislava \\ Radlinského 11, 81005 Bratislava and Gondova 2, 81102 Bratislava \\ SLOVAK REPUBLIC
}

\begin{abstract}
The aim of this paper is to present experience with engineering education of Slovak and foreign students from various countries from Europe, Asia and Africa. The courses in English language are focused on terminologies of 20 different departments of Faculty of Civil Engineering Slovak University of Technology in Bratislava, Slovak Republic. The new ways of engineering education is a part of research realised at Faculty of Art, Comenius University in Bratislava as well. In the frame of the research the following aspects are investigated in practice: internationalization of teaching, teaching innovation and evaluation of the possible teaching improving. The details of teaching are presented and the proposals for research design are outlined. Complete evaluation of these experiments in practice will be published after collecting and processing all necessary data.
\end{abstract}

Key-Words: engineering education, effective teaching, internalization, teaching innovation

Received: March 20, 2021. Revised: August 4, 2021. Accepted: October 6, 2021. Published: October 22, 2021.

\section{Introduction}

Department of Languages, Faculty of Civil Engineering, Slovak University of Technology in Bratislava provides teaching of English and German language in Bachelor study within the first four semesters $[1,2,3]$. The courses are primary focused on various terminologies of 20 different departments: Department of Architecture; Department of Building Construction; Department of Building Services; Department of Building Technology; Department of Concrete Structures and Bridges; Department of Geotechnics; Department of the Humane Sciences; Department of Hydraulic Engineering; Department of Land and Water Resources Management; Department of Languages; Department of Materials Engineering and Physics; Department of Mathematics and Descriptive Geometry; Department of Physical Education; Department of Sanitary and Environmental Engineering; Department of Steel and Timber Structures; Department of Structural Mechanics; Department of Surveying; Department of Theoretical Geodesy and Geoinformatics; Department of Transportation Engineering; Institute for Forensic Engineering.

During every of 4 semesters terminologies of 5 departments are analysed. It is extremely difficult for students to understand the meaning of special terms, which are not in the basic dictionaries and applied them in solving their task also in other subjects.
A teacher has up to 8 groups of students per week. It makes 16 hours per week in the classroom.

Each group may have up to 25 students. A teacher may have altogether up to 200 students in semester.

The participants of the courses consist of Slovak and foreign regular students studying normally 5 years and also for Erasmus foreign students studying in Slovakia only 1-2 semesters. Foreign students are from various countries, e.g. from: Brazil, Greece, Hungary, Kazakhstan, Kenya, Kuwait, Lithuania, Mali, Palestine, Poland, Russia, Spain, Syria, UK, etc.

Internationalization of teaching is necessary to apply together with teaching innovation and evaluation of their results. The research design is the valuable tool for it.

\section{Problem Formulation}

The research design is the direct continuation of the ideas in own proposals and presentations. This research design should explain the research that a teacher is going to undertake to evaluate the impact of internationalization on the learning of his students. It should address the following issues: a) teaching shortcoming prompted the redesign of the course or the design of a new course and explanations why the shortcoming is important to remedy; b) to explain why peer learning is the appropriate choice to address teaching challenge. While do not expect a full-fledged literature review at this point. Details based in description should be 
such that others can borrow proposal of design and implement in their class; c) the expected outcome of the innovation. These should be about an aspect of students' learning including, for example, their attitudes, motivation, knowledge and skills. The reasons behind expectations come from the teaching concept(s) on which innovation is based; d) the data collected to analyze the impact of innovation. The data collection instruments could be survey, graded or ungraded student assignment or exercises, classroom observation, etc.; the collected data should be sufficient to measure the hypotheses/expectations; e) method(s) of analysis to use when analyzing collected data [4]. Qualitative, quantitative or mixed methods. Decision which of the following general categories will be used: doing quantitative analysis, planning to run an OLS or other type of regression, frequencies, chi-squares, difference of means test, etc. Justification why the chosen methods are the most appropriate; f) data collection instruments developed by a teacher, that are not prepared by university or department (i.e., the student evaluation form) or offered by the course (i.e., the classroom observation protocol); g) summary table that summarizes the research design.

\section{Problem Solution}

\subsection{Effective teaching for internalization}

In the past for the design of load-bearing structures in the various countries the different national standards were used. In 1975, the Commission of the European Community decided on an action programme in the field of construction. The objective of the programme was the elimination of technical obstacles to trade and the harmonisation and internationalization of technical specifications. The special type of common European standards should have replaced relevant national standards of all CEN members just months ago. The introduction of Eurocodes eliminates the technical obstacles to trade that existed because of differing design codes in Europe, and will harmonise and internationalize technical specifications, thus creating a more open marketplace. Introduction of Eurocodes, which use terminology different from terminologies used in UK, US, Australia, etc. and in some textbooks is a big challenge for many people including English language teachers. On the other hand Eurocodes enable internationalization of teaching.

The Eurocodes are pan-European structural design codes. There are 10 Eurocodes (EN 1990 to EN 1999) consisting of 58 parts covering [5-14]: a) basis of design; $b$ ) actions on structures (effects of densities, imposed loads on buildings, self weights, traffic loads on bridges, snow loads, wind actions, actions induced by cranes and machinery, accidental actions from impact and explosions, actions in silos and tanks, actions during executions, seismic actions); c) design of structures made of concrete members, d) of steel components, e) of composite steel and concrete elements, f) of timber members, g) of masonry from individual stone or brick units, h) of aluminium alloy members; together with i) geotechnical and $\mathrm{j}$ ) seismic design. They cover the design of bridges, buildings, silos, tanks, pipelines, towers, masts and crane girders.

The Eurocodes are used in 34 European countries which are CEN members. CEN members are the national standards bodies of Austria, Belgium, Bulgaria, Croatia, Cyprus, Czech Republic, Denmark, Estonia, Finland, France, Germany, Greece, Hungary, Iceland, Ireland, Italy, Latvia, Lithuania, Luxembourg, Malta, Netherlands, Norway, Poland, Portugal, Republic of North Macedonia, Romania, Serbia, Slovakia, Slovenia, Spain, Sweden, Switzerland, Turkey and United Kingdom. But the Eurocodes are used also outside of Europe, e.g. in: Malaysia, Singapore, South Africa, Vietnam.

This European Standard was established by CEN in three official versions (English, French, German). A version in any other language is made by translation under the responsibility of a CEN member countries into their own languages. The Eurocodes therefore create the perfect tool for internalization of teaching.

The same is valid also for the European Standard EN 1090 [15] which specifies requirements for execution of steel and aluminium structures, in order to ensure adequate levels of mechanical resistance and stability, serviceability and durability. This European Standard specifies requirements for execution of steel structures in particular those that are designed according to the Eurocodes EN 1993 series, the steel parts of composite steel and concrete structures designed according to the EN 1994 series and according to the Eurocodes EN 1999 series. This European Standard presupposes that the work is carried out with the necessary skill and adequate equipment and resources to perform the work in accordance with the execution specification and the requirements of this European Standard.

The Eurocode English involve new terminology which in some cases differ from UK English, US English or Australian English. For example instead of a term load used in UK, USA or Australia, Eurocodes use two terms: action \& load. It was 
accepted almost in all other languages. In French: action \& charge, in German: e Einwirkung \& e Last, in Spanish: accion \& carga, in Italian: azione \& carichi, in Greek: $\Delta \rho \alpha ́ \sigma \varepsilon ı \varsigma$ (Dráseis) \& Фортía (Fortia). The term action covers effect of loads, imposed deformations and temperature, the term load covers just loadings.

Extremely important is incorporating of the newest terminology of ISO $6707[16,17]$. ISO (the International Organization for Standardization) is a worldwide federation of national standards bodies (ISO member bodies). ISO is a global network of 165 national standards bodies. The work of preparing International Standards is normally carried out through ISO technical committees. Each member body interested in a subject for which a technical committee has been established has the right to be represented on that committee. International organizations, governmental and nongovernmental, in liaison with ISO, also take part in the work.

The students should be familiar also with ISO 3898 [18]. This International Standard covers physical quantities in a general sense. The kernelindex-method enables to form (compound) symbols of physical quantities related to a particular material and/or a particular technical field of design of structures. It also gives the main names, symbols, and units for physical quantities within the field of design of structures.

The European standards: Eurocodes and EN 1090 accept a lot of rules given in ISO 3898 and ISO 6707.

\subsection{Engineering teaching innovation}

Detailed teaching how to design structures according to Eurocodes is based on Bloom's taxonomy and may be described as follows:

1. step: remembering the new (Eurocode) terms.

2. step: understanding by comparison with terms used in the former technical standards in various countries.

3. step: application of the new term in design of some civil engineering structure.

4. step: analyzing identity or diversity with former term.

5. step: evaluation, make judgment which term is more appropriate to describe phenomenon.

6. step: creating own sentences with new term.

To teach so many Slovak and foreign students with different level of English language knowledge is a big challenge for the teachers. If we imagine that the teacher should know not only current but also new terminologies of 20 various departments of Faculty of Civil Engineering introduced by
Eurocodes, it is an extremely difficult task to teach. In the past the following textbook was used in the teaching: English for Civil Engineers by D. Špildová, which contains also English-Slovak vocabulary [1]. Another big challenge is to teach students the special terms. The experience says that it is impossible to do it without figures or schemes.

As the first step of internationalization is using the pictorial dictionary Civil Engineering [2] with the Slovak and English definitions and comments by its authors. Every name of the term (in UK English and in US equivalent if differs) is accompanied by its definition in English and Slovak language and by photograph, picture or scheme. See an example in Figure 1.

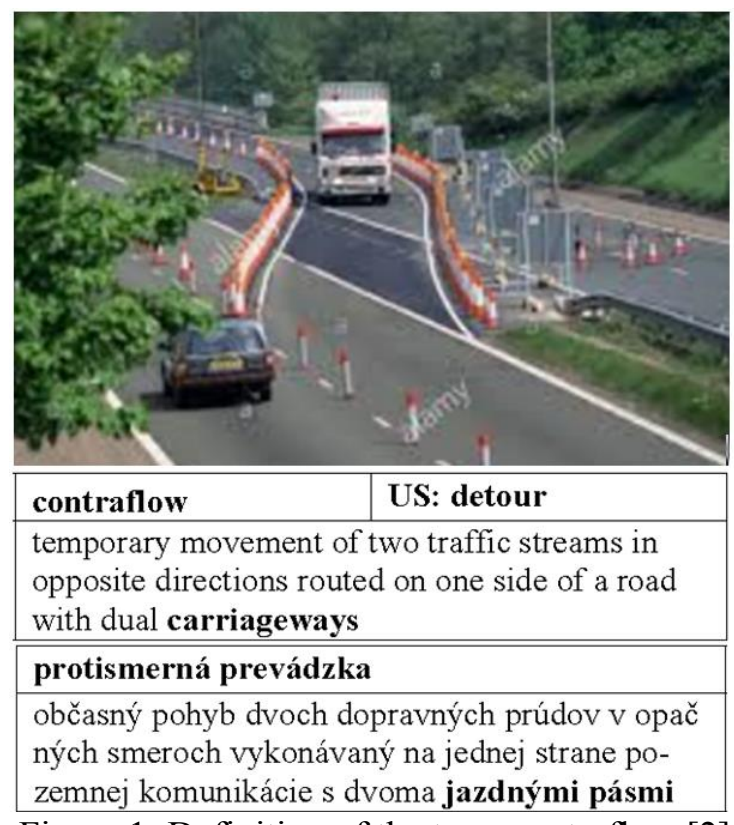

Figure 1: Definition of the term contraflow [2]

As the second step of internationalization of teaching is replacing the textbook [1] by its improved edition without any Slovak word [3].

Example of such way of teaching: a) the term: cable stay (cable-stayed); b) grammatical information: adjective + noun; c) semantic information, English definition: tensioned element which connects the deck of a bridge to the pylon or pylons above the deck; d) synonym of cable: rope; e) pragmatic information, cable stay + noun: cablestayed bridge; f) definition of cable-stayed bridge: bridge, the main structural member(s) of which are cantilevered beam(s) in a deck, supported by a tower and one or more inclined cable(s) connected to the top of the tower; g) use in the context and an example of real bridge: The steel cable-stayed SNP bridge over river Danube in Bratislava (Figure 2) is the former world record holder concerning length 
$303 \mathrm{~m}$ of the main span in category of cable-stayed bridges.

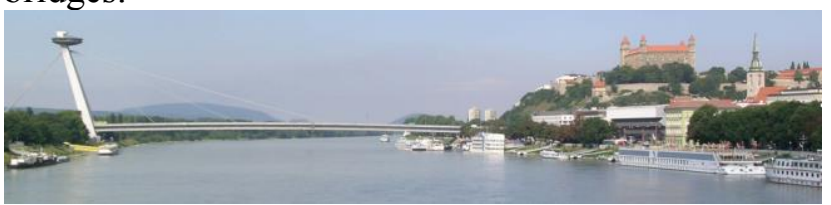

Figure 2: SNP bridge over Danube in Bratislava [2]

Most of the students are eager to know the details of structures holding some world record, e.g. the tallest building, tower or guyed mast, the bridge with the largest main span, the longest bridge, etc.

As internationalization of teaching may be understood the exchange of information about national records of such structures in various countries of students origin. Such game attracts students a lot. They are proud on achievements of their countries. This supports their activities in spoken English within the groups.

Some examples from our education:

a) A Russian student presented the following information: the number one in the ranking of the tallest buildings in Europe is the Lakhta Center building in St. Petersburg with $462 \mathrm{~m}$ height. The first six tallest buildings in Europe are located in Russia. Six of them are in capital Moscow. See Figure $3[20,21]$.

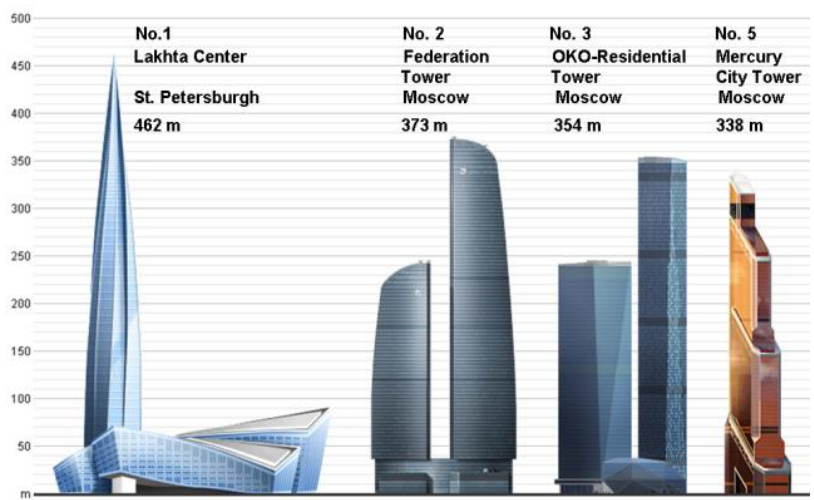

Figure 3: Tallest buildings in Europe and in Russia

b) A girl from Brazil informed other students that they have special type of the suspension bridge in Florianópolis, Santa Catarina state. It has the longest main span in the world $846 \mathrm{~m}$ in the following bridge category: Metal Through Plate Girder Stiffening Eyebar Chain Suspension with fixed and approach spans. Most suspension bridges use cable; this unusual bridge uses eye-bars. The bridge was commissioned by Hercílio Luz, then governor of the state of Santa Catarina. The bridge has name according Luz who died in 1924 two years before bridge opening (Figure 4). c) a boy from Kenya presented the $4^{\text {th }}$ tallest building in Africa located in capital Nairobi and other 7 buildings in Nairobi tall $103 \mathrm{~m}$ to $200 \mathrm{~m}$.

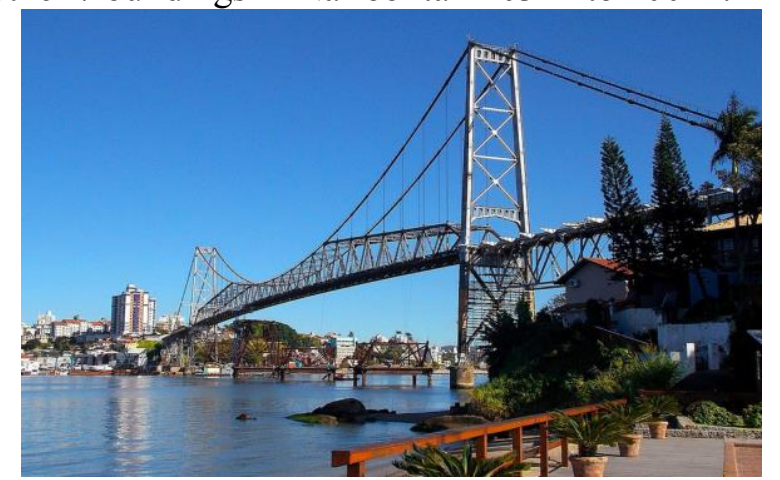

Figure 4: Hercílio Luz bridge, Florianópolis [22]

Hypotheses that teaching: a) based also on visual perception and that $b$ ) the exchange of information about record structures in countries of students origin, will increase the interest of students in learning of English language focused on special terminologies were confirmed.

In the last 20 minutes also non engineering problems are topics of discussions. Students especially like:

a) the ,game“ when they play role of teacher. They explain to others and also to the teacher simpler problems from other subjects which are studied by them also in English language. Such teaching is interesting and source of information not only for students studying other branches, but also for the teacher of English language.

b) their presentations based on papers from Californian STRUCTURE magazine relating problems as: what young engineers should know, lessons for young engineers, investigations and lessons from failures or disasters of different kinds of structures (bridges, buildings, towers etc.), stories about life of famous designers, etc.

c) the solving of tasks from two interesting publications [23, 24]. An example: Barometer is to gasometer as pugilism to ... ? (lightning, protectionism, cruising, bimetallism).

d) foreign-language wordings in English and American literature [25]. An example: ab ovo. $A b$ ovo is Latin for "from the beginning, the origin, the egg". The term is a reference to one of the twin eggs from which Helen of Troy was born. The eggs were laid by Leda after Zeus, disguised as a swan, either seduced and mated with or raped her, according to different versions. Had Leda not laid the egg, Helen would not have been born, so Paris could not have eloped with her, so there would have been no Trojan War. Students become familiar in this way also with Greek mythology. 
e) use of various English word in different proverbs [25]. For example the word cat was found in 44 proverbs and expressions. In this way students become familiar also with books of famous writers. Three examples: Ch. Dickens: Nicholas Nickleby, ch. XII.: "It is enough to make a Tom cat speak French grammar, only to see how she tosses her head". B. Shaw: Platform and Pulpit: "Which of us dare bell this wild cat?" A. Christie: Cat Among the Pigeons, ch. 11.: "There is someone in the schol who merits our very close attention. Cat among the pigeons, in fact."

f) English as it is spoken: colloquial English, slang, cockney dialect [26]. Three examples: bosh (nonsense), chink (money, also prison), lill (little).

g) the importance of green design and sustainable architecture in education of young engineers in all countries is analysed and stressed. Information how this problem is used in the Slovak Republic may be found in [27].

The statement of famous U.S. philosopher Thomas Paine (born Pain) should be motto of all students: that which obtained too easily, we esteem to lightly.

\subsection{Evaluation of new ways of engineering teaching}

Effect of new way of teaching will be measured by comparison of quality of essays, discussions in groups and presentations done by current students with the same activities done by future students. Also by questioning of students who repeat the course, who will be able to compare the old and the new way of teaching. Very good indication will be given in anonymous evaluation forms used at faculty. The possible improving can be measured by: a) evidently better activity of students at tutorials and lectures, and b) directly by improving their study results.

The data collection methods will use assessment instruments included in the syllabus (tests, quizzes, papers, etc.), institutional feedback forms, peer feedback from observing your class and new design additional instruments (own feedback survey, minute papers, quizzes, etc.). To collect good data on the impact of the innovation it is highly recommend using several sources of data and combining them - they can tell us far more than data from a single source.

\section{Conclusion}

Chinese proverb says that a picture is worth of thousand words. But a visit of external works (US: sitework), i.e. visit of construction works or landscape work on land associated with, and adjacent to, civil engineering works or a building or the visit of English event (concert, cinema, conference) is worth of thousands pictures in PowerPoint presentation. COVID-19 pandemic prevents such teaching activities. Humans are social creatures, and they like being together. Computers have made it to be separated but we have all felt that, while we can still work together, it is not just the same.

Especially in the pandemic period there is need to develop Engineering teaching innovation and effective teaching for internationalization.

The paper shows how these problems are solved at Faculty of Civil Engineering Slovak University of Technology in Bratislava by Slovak teachers of English language focused on engineering terminology of 20 different departments. These solutions are applied in the courses for the Slovak and foreign regular students studying normally 5 years and also for Erasmus foreign students studying in Slovakia only 1-2 semesters.

Mutual success of the teacher and the students in English learning depend on both sides. But it is the teacher who can accelerate students' activities by innovation and internationalization of teaching. It must be pleasure for him to devote his time to the students. Only real award for teacher is happy feelings, satisfaction and gratitude of his students.

Teacher itself must continuously improve his knowledge especially when his task is to teach special and changing terminologies of 20 departments.

Teacher must have a lot of patience if he wants fairly evaluate the oral and written work of up 200 students. Teachers at universities are forced to publish a lot of scientific papers in quartile journals and journals in SCOPUS and WOS databases. Especially young teachers who want to create their own family and to live in own flat are in very difficult situation. Under such cruel conditions (many students, changing terminologies of 20 departments, low salary, doing parallel external $\mathrm{PhD}$ study) to do serious and valuable research is poor science-fiction. It is impossible to be very good teacher and in the same time also an excellent researcher. Author of this paper prefers to be the good teacher. She supposes that students too.

\section{Acknowledgement}

This paper did not receive any specific grant from funding agencies in the public, commercial or notfor-profit sectors. 
WSEAS in Greece celebrates the 200 years of independence of Greece (1821-2021). Author would like to thank to WSEAS at this occasion for opportunity to share own experience with the engineering teaching innovation of students from various countries and publish submitted paper without fee.

\section{References:}

[1] Špildová, D., English for civil engineers. 2. overwrought edition, Spektrum STU in Bratislava, 2018, pp. 1-153, ISBN 978-80-2274863-6.

[2] Baláž, I., Balážová, P., Koleková, Y., Civil Engineering, Terms Orbis Pictus 1 (TOP 1), 1.edition, Eurostav, Bratislava, 2017, pp. 1-93, ISBN 978-80-89228-52-2.

[3] Špildová, D., Korbašová, M., New English for Civil Engineers, 1. edition, Spektrum STU in Bratislava, 2020, pp. 1-217, ISBN 978-80-2274993-0.

[4] Bielik, L., Methodology of Science, An Introduction, Comenius University in Bratislava, 2019, pp. 1-210, ISBN 978-80-2234782-2.

[5] EN 1990:2002, Basis of Structural Design, CEN Brussels, Belgium.

[6] EN 1991:2002-2006, Actions on structures. Parts 1.1-1.7, 2, 3, 4, CEN Brussels, Belgium.

[7] EN 1992:2003-2006, Design of concrete structures. Parts 1.1, 1.2, 2, 3, CEN Brussels, Belgium.

[8] EN 1993:2005-2007, Design of steel structures. Parts 1.1-1.12, 2, 3.1, 3.2, 4.1, 4.2 4.3, 5, 6, CEN Brussels, Belgium.

[9] EN 1994:2004-2005, Design of composite steel and concrete structures, Parts 1.1, 1.2, CEN Brussels, Belgium.

[10] EN 1995:2004, Design of timber structures. Parts 1.1, 1.2, 2, CEN Brussels, Belgium.

[11] EN 1996:2005-2006, Design of masonry structure, Parts 1.1, 1.2, 2, 3, CEN Brussels, Belgium.

[12] EN 1997:2004-2007, Geotechnical design. Parts 1, 2, CEN Brussels, Belgium.

[13] EN 1998:2004-2006, Design of structures for earthquake resistance. Parts 1-6, CEN Brussels, Belgium.

[14] EN 1999:2007, Design of aluminium structures, Parts 1.1-1.5, CEN Brussels, Belgium.

[15] EN 1090:2008-2017, Execution of steel structures and aluminium structures, Parts 1.11.5, CEN Brussels, Belgium.
[16] ISO 6707-1:2014, Building and civil engineering works, Vocabulary, Part 1: General terms, $4^{\text {th }}$ edition, ISO Geneva, Switzerland.

[17] ISO 6707-2:2014, Building and civil engineering, Vocabulary, Part 2: Contract terms, $2^{\text {nd }}$ edition, ISO Geneva, Switzerland.

[18] ISO 3898:2013, Bases for design of structures - Notations - General symbols, $4^{\text {th }}$ edition, ISO Geneva, Switzerland.

[19] STN 73 0001:2007, Terminology of Eurocodes, SÚTN Bratislava.

[20] CTBUH, https://www.ctbuh.org/

[21] https://skyscraperpage.com/diagrams/

[22] https://en.wikipedia.org/wiki/Hercilio Luz B ridge

[23] Eysenck, H. J., Know your own IQ, Penguin books Ltd., England, Australia, 1972, pp. 1191.

[24] Eysenck, H. J., Check your own IQ, Penguin books Ltd., England, USA, Australia, 1972, pp. 1-191.

[25] Kunin, A. V., English-Russian phraseological dictionary, Russky Yazik, Moscow, 1984, pp. 1-944.

[26] Kron, R.: The little Londoner, 16th edition, J. Bielefeld Verlag, Freiburg im Breisgau,1921, pp. 1-250.

[27] Balážová, P., Green design and education of students at universities in the Slovak Republic In: GEOLINKS 2021. Book 2, volume 3, extended version: Ecology and Environmental Studies, Environmental Economics, Green Building Technology and Materials, Green Design and Sustainable Architecture, Sofia SAIMA Consult, 2021, ISBN 978-619-749519-5, ISSN 2603-5472, pp. 357-365.

\section{Creative Commons Attribution License 4.0 (Attribution 4.0 International, CC BY 4.0)}

This article is published under the terms of the Creative Commons Attribution License 4.0 https://creativecommons.org/licenses/by/4.0/deed.en US 